\title{
ASSESSMENT OF LARGE DEFORMATIONS ON ROMANESQUE MASONRY PILLARS: THE CASE OF SANTA MARÍA DE ARTIES (XII-XIII) AT VALLE DE ARAN, SPAIN
}

\author{
JOSEP LLUIS I GINOVART ${ }^{1}$, SERGIO COLL-PLA ${ }^{2}$, AGUSTÍ COSTA-JOVER ${ }^{2} \&$ MÓNICA LÓPEZ PIQUER ${ }^{1}$ \\ ${ }^{1}$ Universitat Internacional de Catalunya, Spain. \\ ${ }^{2}$ Universitat Rovira i Virgili, Spain.
}

\begin{abstract}
A set of Romanesque churches at Vall d'Aran, which were built between 11th and 13th centuries, have suffered great deformations and geometrical displacements. In some cases, these deformations have caused the apparition of convex shapes related to the generatrix of the vaults, which are the inverted shape of an arch. Joints have appeared due to the active and passive thrusts as consequence of the interventions made to keep the structures on equilibrium. The church of Santa Maria d'Arties is probably the church where this deformational process is more remarkable. The geometrical assessment of the least rigid elements, the pillars, allows to analyse the displacements which have caused the anti-funicular shapes on some vaults. It is possible to deduce the regression plane of the displacements of the pillars of the central nave, and to define over it the deformation vectors. Thus, the processing of these data allows determining the directions of the deformations of the vaults. The deformations of the pillars are not perpendicular to the axis of the central vault, so the methodology and results can be very useful to understand the nature of the displacements and to maintain those masonry structures.

Keywords: barrel vaults, great deformations, masonry pillars, Romanesque, Valle de Aran.
\end{abstract}

\section{INTRODUCTION}

The churches of Valle de Aran, located at the Spanish Pyrenees, were built between the 11th and 13th centuries. One of the main characteristics of these buildings is the presence of the large deformations in their masonry, which in some cases make up over $7 \%$ of the structure. One of the most deformed buildings is the church of Santa Maria de Arties (XII), the arches and vaults of which have anti-funicular shapes. This anti-funicular shape is the inverse of the natural shape of an arch, since it is convex in relation to its axis. One of the causes of these deformations is the displacement of the pillars since these are the least rigid elements of the structure.

Because of the large deformations, these Romanesque constructions were assessed by several authors, such as Emmanuel Viollet-le-Duc (1814-1879), who visited Bossost (1883) [1], and later by Lluís Domènech i Montaner (1850-1923), who was Dean of the Escuela de Arquitectura de Barcelona (1905) [2]. Subsequently, the Institut d'Estudis Catalans organized an expedition with the combined historical and archaeological purpose of visiting the Valle de Aran and La Ribagorça (1907). Two of the participants were the architects Josep Puig i Cadafalch (1867-1956) and Josep Goday i Casals (1881-1936) [3], who suggested that these churches were initially covered with timber structures, which were later replaced by masonry barrel vaults [4].

Juan Bassegoda i Nonell (1930-2012) stated that formal anomalies are a defining characteristic of the Catalan Romanesque architecture [5]. The case study presented in this paper focuses on the church of Santa Maria d'Arties, which is the most assessed building of this group (Fig. 1). Its great deformations were predicted during the restoration work of the 1970s $[6,7]$. Afterwards, José Luis Villanueva i Bartrina first made an issue of the existence of the 

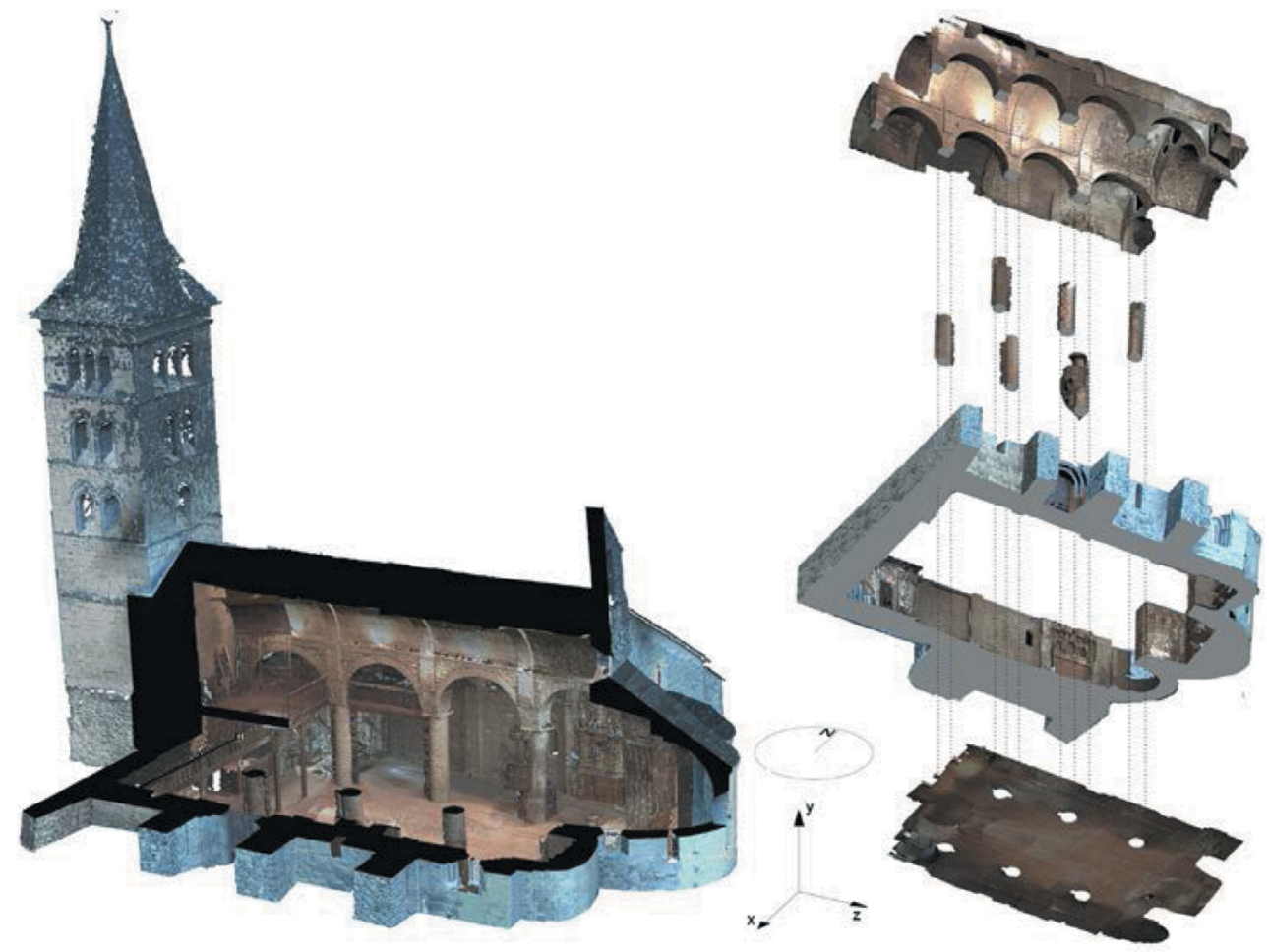

Figure 1: Santa María of Arties.

anti-funicular shapes [8], and in 2009, the structure was assessed by means of finite elements (FEM) by the team of Joan Polo i Berroy [9].

The church of Santa Maria d'Arties can be defined as a rectangular space of about $19.60 \times$ $13.8 \mathrm{~m}^{2}$ until the apsidioles (Fig. 2). This measure is only indicative, as the great deformations make impossible to accurately set the general building measures. The construction is raised with the typical East-West orientation, with a central nave and two collaterals, each with four bays with a span of about $5 \mathrm{~m}$.

The central pillars support the formerets arches located under the gathering of the central barrel vault and the lateral half-vaults. In the western side of the church, a wooden choir is found over the bay of access. The heading is currently finished with a semi-circular apse, reconstructed during last years, and the two original apsidioles. All of them are covered with hemispherical domes. The naves present a typical deformation pattern according to the structural arrangement. Vertical supporting elements, especially the pillars, move abroad because of the thrusts of vaults. The deformation has been measured, in degrees $(\alpha)$, in the wall or column base. Arties has zero degrees in the north vault, one and five in the inner columns and four degrees in the south wall. Therefore, the vaults absorb part of deformation. Arties has a $0.03 \mathrm{~m}$ deformation with a $0.98 \mathrm{~m}$ width. High vaults difference is compared with walls' width and its deformation. At the case study, Arties is the church with greater difference between the keys of the vault, with a $1.91 \mathrm{~m}$ of difference; it has a maximum deformation of $0.21 \mathrm{~m}$. The height and width of the church were compared with the maximum deformation. Arties is $9.76 \mathrm{~m}$ high and $13.86 \mathrm{~m}$ wide, with a $0.03 \mathrm{~m}$ deformation. 


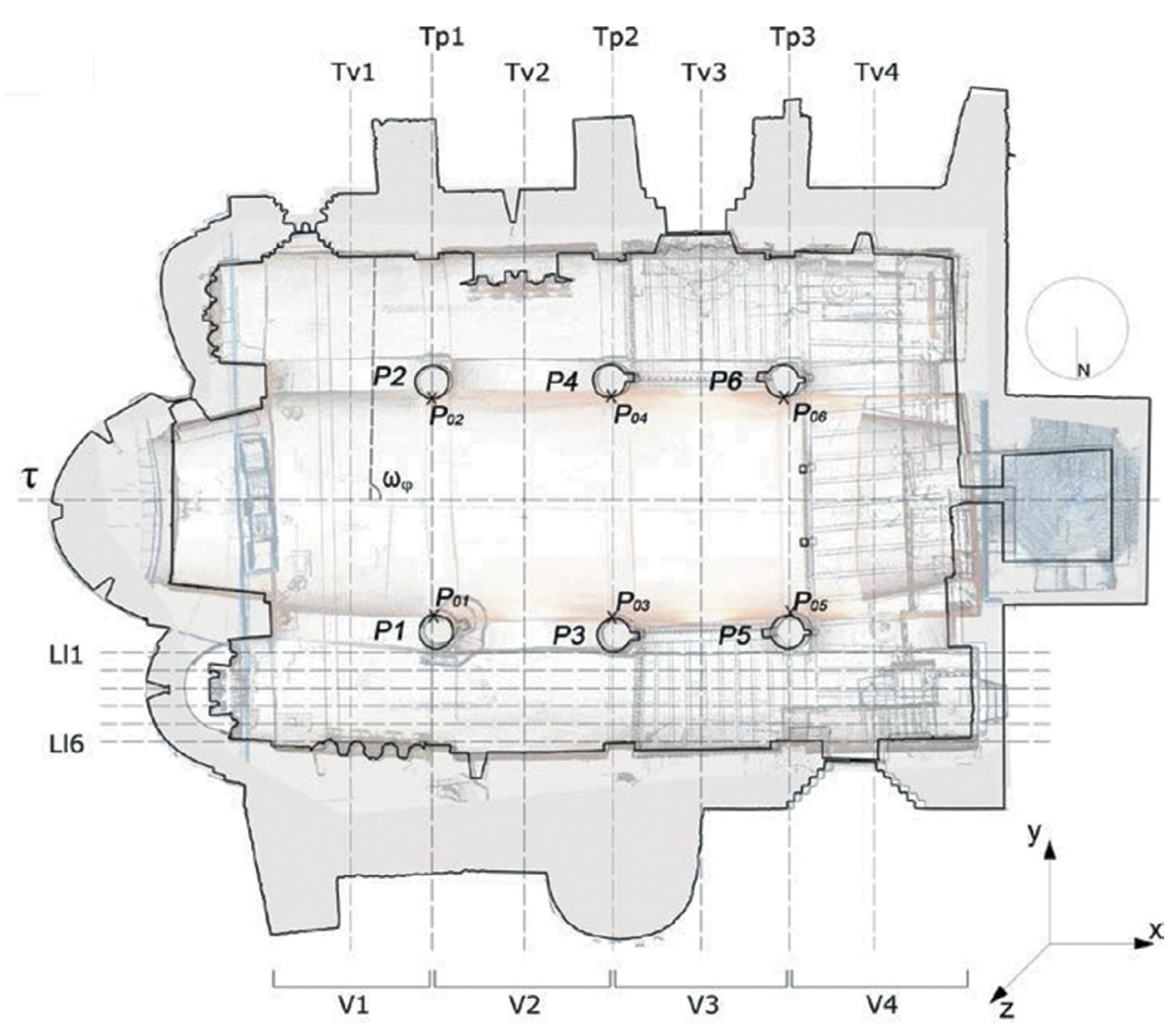

Figure 2: Santa María de Arties. Planimetry and section planes.

\section{OBJECTIVE}

This study focuses on the assessment of the geometrical characteristics of the six pillars $\left[\mathrm{P}_{1} \ldots \mathrm{P}_{6}\right]$ with the objective of studying the displacements that they have suffered [10]. The pillars of the central nave have deformed in a specific way, namely, through the masonry joints $\left(n_{\mathrm{s}}\right)$. These joints are perfectly visible on pillars $\mathrm{P}_{3}, \mathrm{P}_{4}, \mathrm{P}_{5}$ and $\mathrm{P}_{6}$, while they are more difficult to see on $\mathrm{P}_{1}$ and $\mathrm{P}_{2}$, since these pillars are partially covered by mural paintings. The displacements can be assessed according to the coordinates of the centroid of each row $\left(x_{\mathrm{ci}}\right.$, $\left.y_{\mathrm{ci}}, z_{\mathrm{ci}}\right)$, and the point of reference is taken from the row of the floor plan, which is considered to be undeformable. This establishes the coordinates as $\left(x_{\mathrm{ci}}, 0, z_{\mathrm{ci}}\right)$. These points allow one to define a regression plane $\mathrm{P}_{\mathrm{ri}}$ for each pillar. Thus, it is possible to define a vector of deformation contained on each plane $\left[\mathrm{P}_{\mathrm{r} 1} \ldots \mathrm{P}_{\mathrm{r} 6}\right]$. Finally, these data allow one to determine the general tendency of the deformation of the vaults.

\section{METHODOLOGY}

\subsection{Scanned data obtained}

The assessment is based on a three-dimensional model obtained with a terrestrial laser scanner (TLS). In the assessment of built heritage, the use of direct measurement techniques for 
architectural surveying requires a large number of resources. The use of massive data capture techniques, such as TLS, has recently become prominent in surveying architectural heritage [11]. It is a contactless, non-invasive surveying technique that allows for the massive capture of geometric and radiometric data of a given surface [12]. Thus, it allows for a quick and easy capture of the geometry of objects. The main limitations lie in the management of dense point clouds, the texturization of surfaces and the need to place the device in a stable position. In addition, cost is a very important limiting factor.

The scanner used is a Leica ScanStation P20, with a bandwidth of 808/658, class 1 . The scanning ratio is $1,000,000$ points, and the noise at 100 is $9.0 \mathrm{~mm}$ for black surfaces, 4.30 $\mathrm{mm}$ for grey surfaces, and $1.5 \mathrm{~mm}$ for white surfaces. The field of view is $360^{\circ}$ horizontal and $270^{\circ}$ vertical. The point cloud is processed with the software Cyclone, and the program 3DReshaper is used to obtain the three-dimensional mesh with an average distance of points of $5 \mathrm{~cm}$ as well as a measure of the triangle for detecting $10 \mathrm{~cm}$ holes. The model of the interior of the building has 80.582 points and 156.449 triangles, and the exterior has 314.650 points and 609.472 triangles.

After that the Cyclone software is used. The use of the specific software Cyclone to process the data makes it possible to visualize the point cloud obtained and to process and join all of the scans. This processing occurs through an automatic process with slight manual adjustments, and a complete, depurated point cloud is obtained.

The assessment of the shapes can only be understood in three dimensions through an interval $(a, b)$, which has to impose the condition of equilibrium according to the elastic theory with the summation of the active thrusts $\left(E_{\mathrm{ba}}\right)$ of the vaults and the passive thrusts of the walls $\left(E_{\mathrm{mp}}\right)$ and buttresses $\left(E_{\mathrm{mc}}\right)$.

$$
\begin{aligned}
& \sum_{b}^{a} F_{(\mathrm{x}, \mathrm{y}, \mathrm{z})}\left(E_{\mathrm{ba}}+E_{\mathrm{mp}}+E_{\mathrm{mc}}\right)=0 . \\
& \sum_{b}^{a} M_{(\mathrm{x}, \mathrm{y}, \mathrm{z})}\left(E_{\mathrm{ba}}+E_{\mathrm{mp}}+E_{\mathrm{mc}}\right)=0 .
\end{aligned}
$$

The assessment of the deformations of the elements under its own weight, especially the central and collateral vaults, makes it possible to deduce that external actions, such as snow or seism, together with the loss of lime mortar due to humidity or vibrations causes the primitive function $\mathrm{f}(\mathrm{x}, \mathrm{y}, \mathrm{z})$ of the vaults, which is unknown, to tend to deform into the function $\mathrm{ff}(\mathrm{x}, \mathrm{y}, \mathrm{z})$, which is obtained through the topographical survey.

\subsection{Deformations on vaults and pillars}

From the point of view of historiography, Emmanuel Viollet-le-Duc (1814-1879) assessed the barrel vaults and the abutment with timber beams with more precision [13]. August Choisy (1841-1909) did not explain the Romanesque vaults, but did explain the barrel vault as originating from Roman construction with brick and concrete [14]. He referred to the byzantine influence on construction with or without centring [15]. Otherwise, in the work Historia General del Arte (1901), Josep Puig i Cadafalch described the great difference between the Romanesque vaults, where elasticity is replaced by stability, a concept inherited from roman vaults, which were significantly more monolithic [16]. 
When the geometry of these vaults is regular and the construction is monolithic due to the masonry disposition, the thrust is perpendicular to its guideline. Thus, the thrust of a vault is determined through the following function:

$$
E_{\mathrm{b}}\left(E_{\mathrm{bx}}, E_{\mathrm{by}}, E_{\mathrm{bz}}\right)
$$

If we consider homogeneous vaults with a constant guideline, the vector of this thrust would be, according to Choisy [14], as follows:

$$
E_{\mathrm{b}}\left(E_{\mathrm{bx}}, 0,0\right)
$$

Conversely, barrel vaults of Vall d'Aran churches have specific features. These are conic vaults, as was theorized by Joan Bassegoda [5], and stone-cutting is not regular, as stated by Josep Puig i Cadafalch [16]. Finally, the supports of the vaults, external walls and arches, have a different stiffness, as noted by Luis Villanueva [8]. Those three conditions are far from the general theory of the thrust of homogeneous vaults with cylindrical guideline. In addition, the assessment of the pillar deformations and their stiffness is influenced by the contributions of Josep Puig i Cadafalch (1907).

In any or in a combination of the precedent hypotheses, thrusts work in two directions $(x, z)$ as long as the supports stand still. Thus, the resultant force is not perpendicular to the guideline of the vault (Fig. 3). The general vectorization in those cases can be defined as the thrust of the vault $E_{\mathrm{b}}\left(E_{\mathrm{bx}}, E_{\mathrm{by}}, E_{\mathrm{bz}}\right)$, and deformations can occur in two directions:

$$
f\left(d f_{\mathrm{x}}, 0, d f_{\mathrm{z}}\right)
$$

The forces caused by the vaults are transmitted to vertical structural elements. The vaults of the central nave are supported by the walls over former arches, which at the same time are supported by the pillars of the central nave. Thus, the elements can deform over the three planes, pillars $d f_{\mathrm{p}}\left(d f_{\mathrm{px}}, d f_{\mathrm{py}}, d f_{\mathrm{pz}}\right)$, and perimeter walls $d f_{\mathrm{m}}\left(d f_{\mathrm{mx}}, d f_{\mathrm{my}}, d f_{\mathrm{mz}}\right)$.

The displacement of the pillar can be deduced through analysis of the displacement of the centroid of $n$ sections $\left(n_{\mathrm{s}}\right)$ of the pillar. Thus, coordinates $\left(x_{\mathrm{ci}}, y_{\mathrm{c},}, z_{\mathrm{ci}}\right)$ are set for each section $\left(n_{\mathrm{s}}\right)$. The centroid of reference $\left(x_{\mathrm{c} 0}, y_{\mathrm{c} 0}, z_{\mathrm{c} 0}\right)$ is set in the section of the floor plan since it would have not suffered any displacement. The final section is located at the impost of the pillar $\left(x_{\mathrm{cs}}, y_{\mathrm{cs}}, z_{\mathrm{cs}}\right)$. The obtained points define a function $f\left({ }_{\mathrm{ci}}\right)$, which makes it possible to deduce the regression plane $\mathrm{P}_{\mathrm{ri}}$. It characterizes the tendency of the displacement vectors of the structural section supported by the pillar (Fig. 4).

The assessment of this displacement vector determines the clearance angle $(\omega)$ of the regression plane $\mathrm{P}_{\mathrm{ri}}$ of the plane over the directrix of the vault $(\tau)$. Thus, this angle can be understood as:

(a) $\left(\omega_{\varphi}\right)=90^{\circ}$, perpendicular to the directrix $\varphi_{1}$,

(b) $\left(\omega_{\varphi}\right)<90^{\circ}$, displacement towards the apse,

(c) $\left(\omega_{\varphi}\right)>90^{\circ}$, displacement towards the façade.

The reparation and containment of these deformations are the cause of the reinforcement of the perimeter walls by means of the construction of buttresses or strategical placement of bell towers, which are usually built in the façade opposite to the apse. The active thrusts $\left(E_{\mathrm{ba}}\right)$ of the vaults over pillars and walls have been determined, but to understand the equilibrium 


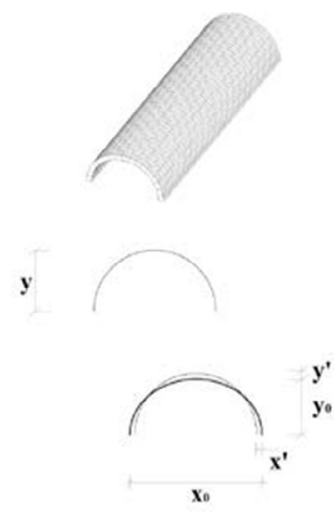

Cannon vaults; Regular geometry and cutting
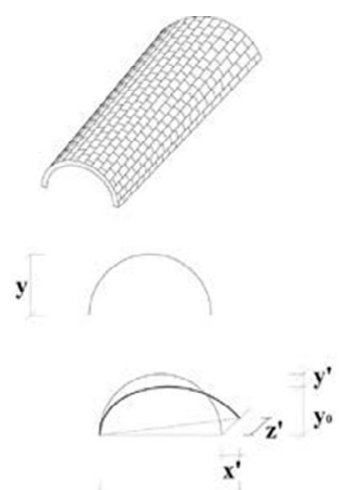

$\mathrm{x}_{6}$

Conical vaults; Irregular geometry and regular cutting
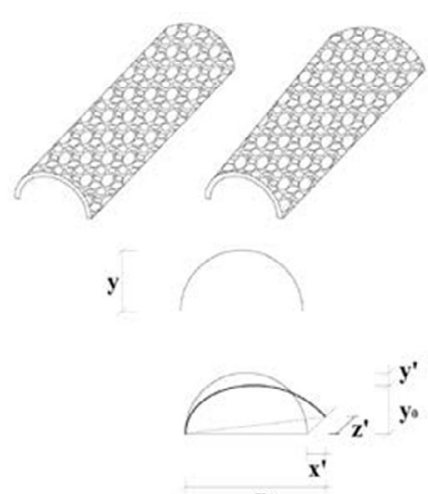

$\mathrm{x}_{\mathrm{e}}$

Cannon and conical vaults; Irregular geometry and cutting

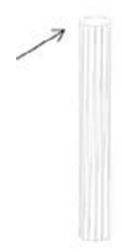

Monolithic pillars
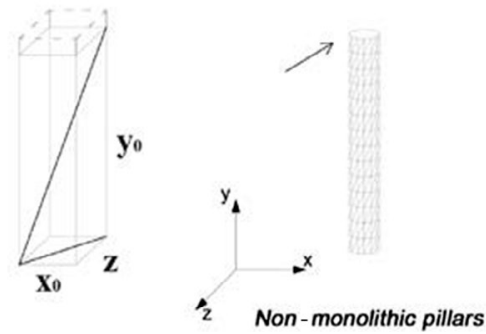

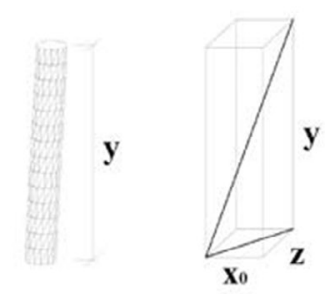

Figure 3: Characterization of the thrusts on vaults.

of these constructions, it is essential to understand the passive thrusts of the buttressing elements: walls $\left(E_{\mathrm{mp}}\right)$ and buttresses $\left(E_{\mathrm{mc}}\right)$. Because of these thrusts, some vaults have deformed towards anti-funicular shapes.

\subsection{Process of study}

The point cloud is processed with the program 3D Reshaper to obtain the displacement vector and the clearance angle $(\omega)$. The first step is the isolation of every pillar shaft. The

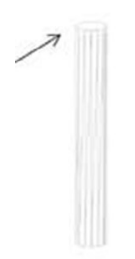

Monolithic pillars

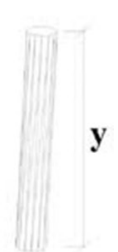

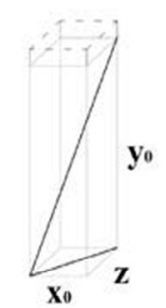

$\mathbf{X}_{0}$

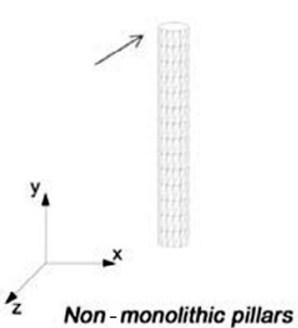

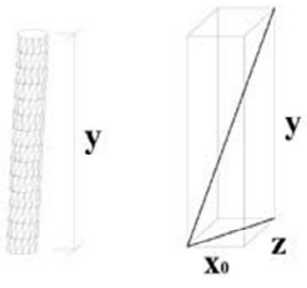

$\mathbf{X}_{0}$

Figure 4: Characterization of the thrusts on vaults pillars. 
height of these elements is variable, and in most of them, there is no clear base or capital, so the measure of the shaft is defined between the encounter with the floor and the springs of the arches.

The second step consists of the definition of the stone rows and then a cross section is made on each of them. The process is performed manually, since the irregular shape of the slabs caused excessive errors with more automated procedures. The contour and the barycentre is defined for each of the cross sections, which allow to obtain the area and the central axis respectively. The area allows to deduce the springing of the arches in the cases where there are not any impost.

The assessment of the barycentres is used to know the displacements of the pillars. These elements have a compressed part and another under tensile strength, so the central axis is the only part that can explain their shape. This is deduced from the union of all the barycentres of each cross section. Two operations are performed with this line: first, the projection over the horizontal plane to know the direction of axis $(\tau)$. Second, the projection over the plane which crosses the axis of maximum deformation.

\section{RESULTS}

Results are drawn over the floor plan, where the relation between the regression planes $\mathrm{P}_{\mathrm{ri}}$ and the clearance angle $(\omega)$ is shown.

The greatest displacement is found in pillar P1 (Table 1), with a range of displacement on each row of [0.270, 0.001]. That displacement is followed by that in pillar P3, with a range of $[0.190,0.001]$. The range of displacements of the rest of the pillars is as follows: P2 [0.108, 0.002], P4 [0.109, 0.002], P5 [0.101, 0.001], and finally, the least deformed pillar, P6 [0.065, 0.001]. Thus, pillars P1, P3 and P5 have greater deformations than the others. These are located in the North face, where a massive buttress of $131.04 \mathrm{~m}^{3}$ was built, which causes a passive thrust (Emc). The wall at the south face has a volume of $179.91 \mathrm{~m}^{3}$, which was later reinforced with four buttresses of $44.96 \mathrm{~m}^{3}$.

None of the regression planes $\mathrm{P}_{\mathrm{ri}}$ is perpendicular to the axis of the central vault, and so each one is slightly sloped. The most leaned pillar is found in $\mathrm{P}_{1}$, with a horizontal displacement of $0.270 \mathrm{~m}$. The angle between the regression plane and the central axis is $85.466^{\circ}$, which is $\left(\omega_{\varphi}\right)<90^{\circ}$ (Fig. 5). The angle at the rest of the have the following values $\left(\omega_{\varphi}\right)>$ $90^{\circ}$, with a range of $\left[103.893^{\circ}, 126.169^{\circ}\right]:\left[\mathrm{P}_{2} ; 103,893^{\circ}\right],\left[\mathrm{P}_{3} ; 108,665^{\circ}\right],\left[\mathrm{P}_{4} ; 117,245^{\circ}\right],\left[\mathrm{P}_{5}\right.$; $\left.112,066^{\circ}\right]$ and $\left[\mathrm{P}_{6} ; 126,169^{\circ}\right]$.

Moreover, $\mathrm{P}_{1}$ is not only the most inclined pillar $(0.270 \mathrm{~m})$, but also is the highest $(4.170 \mathrm{~m})$. About the rest of the pillars, $\mathrm{P}_{2}$ has leaned $(0.108 \mathrm{~m})$, and is the second highest pillar (3.940 $\mathrm{m})$. Pillar $\mathrm{P}_{3}$ has leaned $(0.190 \mathrm{~m})$ and has a height of $(3.888 \mathrm{~m})$, pillar $\mathrm{P}_{4}$ has leaned $(0.109 \mathrm{~m})$ and has a height of $(3.930 \mathrm{~m})$, pillar $\mathrm{P}_{5}$ has leaned $(0.101 \mathrm{~m})$ and has a height of $(3.587 \mathrm{~m})$ and finally pillar $\mathrm{P}_{6}$ has leaned $(0.065 \mathrm{~m})$ and has a height of $(3.684 \mathrm{~m})$. (Table 1$)$

These data reveal that the leaning is proportional to the height of the pillar. In addition, northern pillars are less out of plum than the southern ones.

\section{DISCUSSION AND CONCLUSION}

The main factor of pillar deformation is the vault height. It gets obvious in the study of vector deformation. The forces caused by the vaults are transmitted to vertical structural elements. The vaults of the central nave are supported by the walls over former arches, which at the same time are supported by the pillars of the central nave.

The displacement of the pillar deduced through analysis of the displacement of the centroid of $n$ sections $\left(n_{\mathrm{s}}\right)$ of the pillar can be studied the direction and vector magnitude. In relation 


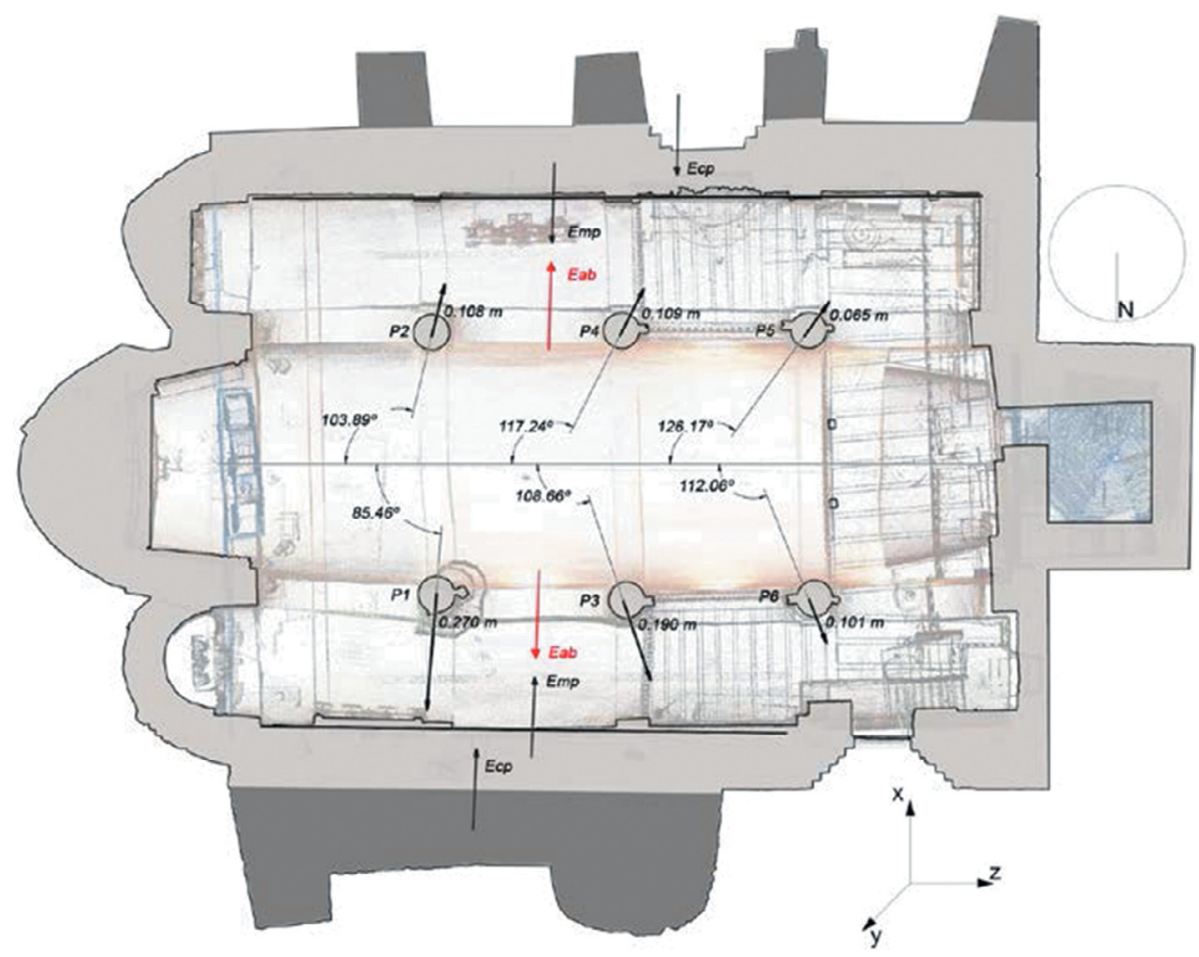

Figure 5: Characterization of the regression planes $\mathrm{P}_{\mathrm{ri}}$.

to the direction of the vector, the obtained regression planes $\mathrm{P}_{\mathrm{ri}}$, which contain the deformations $d f_{\mathrm{p}}\left(d f_{\mathrm{px}}, d f_{\mathrm{py}}, d f_{\mathrm{pz}}\right)$ for each pillar, tend to have the direction of the thrust over the pillar $\mathrm{P}_{\mathrm{i}}$. These displacements are the result of the active thrusts of vaults and the passive thrusts of the buttressing system, walls $\left(E_{\mathrm{ba}}\right)$ and the passive thrusts of the buttressing system, walls $\left(E_{\mathrm{mp}}\right)$ and buttresses $\left(E_{\mathrm{mc}}\right)$.

This study revealed that the direction of the displacements of the six pillars $\mathrm{P}_{\mathrm{i}}$ is not perpendicular to the central axis of the church $\varphi_{1}$, since $\left(\omega_{\varphi}\right) \neq 90^{\circ}$. This result proves the hypothesis

Table 1: Characteristics of the displacement vector (the angles refer to the inclination of the vector in respect to the vertical).

Pillars Max.Disp.X Min.Disp.X Angle Pillar length Pillar height $\operatorname{Cos}\left(^{\circ}\right)-(\mathbf{P 1} / \mathrm{Ph})$

\begin{tabular}{lcccccc}
\hline & $(\mathbf{M})$ & $(\mathbf{M})$ & $\left(^{\circ}\right)$ & $(\mathbf{M})$ & $(\mathbf{M})$ & $\left(^{\circ}\right)$ \\
P1 & 0.270 & 0.001 & 3.780 & 4.183 & 4.170 & 0.200 \\
P2 & 0.108 & 0.200 & 1.780 & 3.930 & 3.940 & 0.790 \\
P3 & 0.190 & 0.001 & 2.850 & 3.890 & 3.888 & 0.043 \\
P4 & 0.109 & 0.002 & 1.710 & 3.774 & 3.770 & 0.862 \\
P5 & 0.101 & 0.001 & 1.670 & 3.590 & 3.587 & 0.902 \\
P6 & 0.065 & 0.001 & 1.170 & 3.687 & 3.684 & 0.611 \\
\hline Max & $\mathbf{0 . 2 7 0}$ & $\mathbf{0 . 0 0 2}$ & $\mathbf{3 . 7 8 0}$ & $\mathbf{4 . 1 8 3}$ & $\mathbf{4 . 1 7 0}$ & $\mathbf{0 . 2 0 0}$ \\
Min & $\mathbf{0 . 0 6 5}$ & $\mathbf{0 . 0 0 1}$ & $\mathbf{1 . 1 7 0}$ & $\mathbf{3 . 5 9 0}$ & $\mathbf{3 . 5 8 7}$ & $\mathbf{0 . 6 1 1}$ \\
Average & $\mathbf{0 . 1 4 1}$ & $\mathbf{0 . 0 0 1}$ & $\mathbf{2 . 1 6 0}$ & $\mathbf{3 . 8 4 2}$ & $\mathbf{3 . 8 4 0}$ & $\mathbf{0 . 4 4 5}$ \\
\hline
\end{tabular}


that the thrusts of the vaults are not perpendicular to the axis of the church, as was the case in Roman vaults, which Choisy [14] defined with regular geometry and stone-cutting.*** The direction of displacements is caused by the irregular geometry of the vaults of Santa Maria de Arties as well as the masonry stone-cutting and the above mentioned passive thrusts of the walls and buttresses. The last ones were placed to maintain equilibrium during the last millennium.

The displacement of the five pillars $\left(\mathrm{P}_{2} \ldots \mathrm{P}_{5}\right)$, where $\left(\omega_{\varphi}\right)>90^{\circ}$, tends to the opposite façade of the apse. In addition, pillars $\mathrm{P}_{5}$ and $\mathrm{P}_{6}$, built during 12th century on that façade, are the least deformed pillars because of two subsequent transformations: the construction of the bell tower over the centre of the façade (XIII-XIV) and the wood choir (XVIII). These elements have a stiffening function. Pillar $\mathrm{P}_{1}$ is the most deformed pillar of Santa Maria de Arties and has $\left(\omega_{\varphi}\right)<90^{\circ}$ over the main axis. The displacement tends to the apse. This pillar, together with pillar $\mathrm{P}_{3}$, where $\left(\omega_{\varphi}\right)>90^{\circ}$, is located where a great balancing was achieved through the passive thrust of the walls $\left(E_{\mathrm{mp}}\right)$ and buttresses $\left(E_{\mathrm{mc}}\right)$.

Figure 5 shows that the direction of deformation does not coincide with the butress location. For example, the $\mathrm{P} 2$ deformation is directed to wall span. The same situation occurs in the P6 of the North façade. From another point of view, the buttress construction allows the interpretation of anti-funicular shapes. The specific weight is more than $24 \mathrm{kN} / \mathrm{m}^{3}$, and the buttressing system weighs $3,144.96 \mathrm{kN}$. This is where anti-funicular shapes have appeared, which are inverted arches, so $\mathrm{ff}^{\prime \prime}(\mathrm{x})>0$. The reparation and containment of these deformations are the cause of the reinforcement of the perimeter walls by means of the construction of buttresses or strategical placement of bell towers, which are usually built in the façade opposite to the apse. The active thrusts $\left(E_{\mathrm{ba}}\right)$ of the vaults over pillars and walls have been determined, but to understand the equilibrium of these constructions, it is essential to understand the passive thrusts of the buttressing elements: walls $\left(E_{\mathrm{mp}}\right)$ and buttresses $\left(E_{\mathrm{mc}}\right)$. Due to these thrusts, some vaults have deformed towards anti-funicular shapes.

As far as the pillar deformation magnitude is concerned, $\mathrm{P}_{1}$ is the most deformed pillar of Santa Maria de Arties with $0.270 \mathrm{~m}$ deformation. P3 pillar follows it with a deformation of $0.190 \mathrm{~m}$. This fact is coincident with the embankment of the ground.

Another explanation to justify the less deformation of pillars $\left(\mathrm{P}_{3}, \mathrm{P}_{4}, \mathrm{P}_{5}, \mathrm{P}_{6}\right)$ is that they are in contact with the wood joists of the choirs. The wood makes a job helping on the traction. The $\mathrm{P}_{3}$ and $\mathrm{P}_{4}$ pillars have two intermediate wood ties and they show a $0.190 \mathrm{~m}$ and $0.109 \mathrm{~m}$ deformation. P5 and P6 pillars show a $0.101 \mathrm{~m}$ and $0.065 \mathrm{~m}$ deformation and they are connected to three wood ties.

Another important piece of data is the one obtained from the relation between the pillar length and height. The trigonometric relation of the cosinus angle minus the difference between the pillar length and pillar heights must be zero. It shows that none of the pillars has a straight axis. To understand this result, it is needed to study the development of the axis along the pillar.

\section{REFERENCES}

[1] Español, F., El Pirineu Desvetllat. Viatges i descoberta del Patrimoni Medieval. Ibix : publicació biennal de cultura. Ripoll: Annals, 7, pp. 13-36, 2010.

[2] Granell, E. \& Ramon, A., Lluís Domènech i Montaner. Viatges per l'arquitectura romànica catalana. Barcelona: Colegio de Arquitectos de Cataluña, 2006.

[3] Alcolea Blanch, S., La missió arqueológica del 1907 als Pirineus. Exhibition catalog. Colegio de Arquitectos de Cataluña, Barcelona, 2008. 
[4] Puig i Cadafalch, J., Les esglesies romániques amb cobertes de fusta de les valls de Boí I d'Arán. Barcelona: Institut d'Estudis Catalans, 1907.

[5] Bassegoda, N., Estética expresionista de la arquitectura románica lombarda en Catalunya como consecuencia de las deformaciones formales y estructurales de las iglesias. De Re Restauratoria, Vol II, Catedra Gaudi UPB: Barcelona, pp. 33-64, 1974.

[6] Bassegoda Nonell, J. La Iglesia de Santa María de Arties, barroca y racionalista. Un templo sin cimientos. La Vanguardia Española, pp. 51, Jueves 28 de septiembre 1972.

[7] Saez, G., Primera fase del proyecto de restauración de la Iglesia de Santa María de Artíes en el Valle de Arán (Lérida). Cuad. Arquit. Urban., 116, pp. 63-71, 1976.

[8] Villanueva, J.L., Las bóvedas de cañon. De Re Restauratoria, Vol. II, Catedra Gaudi UPB: Barcelona, pp. 145-158, 1974.

[9] Polo, C., Santa Maria d'Arties (Naut Aran, Val d'Aran): Un exemple integrau a niveu de restauracion d'un monument a compdar des entresenhes arqueologiques. Cicle conferències Patrim. Arqueol. i Arquit. a les Terres Lleida 2009: Lleida, pp. 75-103, 2009.

[10] Lluis i Ginovart, J., Costa-Jover, A. \& Coll-Pla, S., La determinación del concepto de homogeneidad versus resistencia en los pilares de una catedral gótica mediante técnicas no invasivas. Inf. la Construcción, 68(543), 2016. DOI: 10.3989/ic.15.119.

[11] Lluis i Ginovart, J., Costa-Jover, A., \& Coll-Pla, S., Techniques of massive data capture: A comparative approach for the assessment of complex spaces in architectural heritage. Rev. la Construcción, 15(1), pp. 42-50, 2016. DOI: 10.4067/S0718-915X2016000100004.

[12] Pesci, E., Bonali, A., Galli, C. \& Boschi, E., Laser scanning and digital imaging for the investigation of an ancient building: Palazzo d'Accursio study case (Bologna, Italy). Journal of Cultural Heritage, 13(2), pp. 215-220, 2012. DOI: 10.1016/j. culher.2011.09.004.

[13] Viollet-le-Duc, E., Dictionnaire raisonné de l'architecture française du XIe au XVIe siècle, A. Morel: Paris.

[14] Choisy, A., L'art de batir chez les Romains, Ducher et Cie: Paris, 1873.

[15] Choisy, A., L'art de batir chez les Byzantins, Librairies de la Sociètè Anonyme de Publications Périodiques: Paris, 1883.

[16] Puig i Cadafalch, J., Historia General del Arte. Escrita y editada en vista de los monumentos y de las mejores obras publicadas hasta el dia, bajo la dirección del arquitecto Don José Puig i Cadafach. Arquitectura. Tomo Segundo, Montaner y Simón Editores: Barcelona, 1901. 